trouble are known to have been congenital, others were caused by trauma. The abovc writers call attention to the venous nature of the Pacchionian granulations (bodies), and to their thinning the cranium over them. In cases where they perforate the bone, it is imagined that such a subpericranial venous tumour might result. This theory might be perfected by remembering that, when the bone had become much thinned at any point by granulations, a slight blow would suffice to finish the perforation. But, as shown above, the granulations presenting the most venous characteristics do not, as a rule, penctrate much into the bone. Althongh it is often stated that the granulations occasionally perforate the bone overlying them, it is difficult to find actual cases in the literature. Pozzi quotes from Webcr Ribes (Bull. d. la F'aculté d. Méd., Paris, 1819, p. 303) a case of such perforation, where the hole of the opening was sinall and surrounded by smooth bone. A ligamentous covering completely closed thc opening. There are, however, many cases recorded where the bone had been reduced to paper thinness.

That these growths do not oftener perforate the cranium is due perhaps to several causes. Whatever occasions their development has doubtless ceased to act before they get that far. Again, at tbis vcry point, where their force slackens, they meet the hard external plate, and are able to go no farthcr.

The new data used in this article were collected eitlier at the Anatomical Institute, Leipsic, or at the German Hospital, New York.

\title{
Anticle IV.
}

Eye Diseaste Dependext uron Sepression of Mensys. By Real) J. Moka Y, M.D., of Wilmington, Delaware, Member of the Amcrican Ophthalmological Society.

For several years past, it has been my endeavour to present to the annual meeting of the Delaware State Medical Society (wherc I had cxpected to read this paper this year, but was unable to attend to do so), practical papers upon eye or car diseases, hoping thereby the more readily and pronptly to promulgate the frequent and important relations existing between those diseases and general diseases, as our knowledge of special diseases increases in extent and exactness; and $I$ have attempted to use language frec from obscuring and mystifying tcchnicalities, in order that the obscrvations might be fully comprehended, for I have frequently thought specialists generally, by the manner in which they present important medical topics to their professional brethren in general practice, and to students in the lecture-room, fail to make the agreeable, intelligent, and lasting impressions which are always desirable and appreciated. 
I now desire to present for consideration some clinical histories and practical remarks upon cases of eye diseases dependent upon abnormal menstruation, which have been under my care during tle past nine years. As they arc not very numerous I venture to report them fully, so that they may be studied critically. They only includc cases of eye diseases caused or complicated by suppression of menses.

CAsE I._Fannie R., aged 22 years, single, domestic, United States, first came under my care at out-door department of Bellerue Hospital, New York City, June 30,1873. She had had doublc-sight at intervals for two weeks past, and could not read or sew. Slue suffered with supra-orbital neuralgia. 'Two years previously sle had suppression of menses. Since then her menses have been irregular, and the flow diminished in quantity. Vision of R. E. $=\frac{1}{5} \frac{6}{0}$, of L. E. $=\frac{1}{8} \frac{6}{0}$, and slie could see small type ten inclies. Slie was slightly myopic, but did not require glasses. Her pupils actcd sluggishly under light. Ophthalmoscopic exanination manifested appearances of well-marked neuro-retinitis. Frce catharsis and bleeding of temples promptly improved her vision somewhat, and tonics har general health, when her menses became regular and she could again use her eyes. This improvement continued for several months, until suppression again occurred fiom getting ler fect wet during " tles flow," and again her eyes could not be used as desircl. Several months later her menses again appeared and her eycs regained thcir normal condition. In March, 1875, slie reported she had had a recurrence of partial suppression and eye troubles. In October, 1876, reportcd monses regular witlout any eye trouble, and her general health good, which continued a year later, the last report made to mc.

$\mathrm{C}_{A S E}$ II.-Flizabeth H., German, agcd 19 ycars, single, domestic, had been in United States over tliree years, came to "Bellerue Out-door" Dept." July 6, 1874, for treatment for her eyes. At 14 years of age first had her menses, and not again until she was 18 years old, and the last time six or seven months previously. Eight days ago she began to havc sevcre lieadaches, which preventcd her slccping well for several niglits. Slue reported that when her headache was severc she had intense dread of light, but none witlout the pain in her hear. Her near vision was good. Ophthalmoscopic examination revealed optic neuritis and retinal hyperæmia, which was more marked two days later, when slie manifested symptoms of brain and spinal cord disease, and was sent to the hospital, passing from under observation.

CAsE III.-Lucy J., aged 15, resident in New Jersey, came to the clinic at "Bellevue Out-door Dept." August 19, 1874, for dimness of her eyesight. She was very tall and large for her age. When five years old she had liad a severe attack of cxternal infaimmation of her eyes (probably plilyctchular conjunctivitis). She lias not been sick otherwise, exccpting a weakness of lier back, which began at 12 years of agc. It was worse at time of menstruation, which began at 14 ycars of age, and she reported she had always been regular. About a year ago, when her menses first appeared, her eyesight began to grow dim, and lias gradually grown worse. Six montlis ago fiequent attacks of severe lieadaclie commenced, which lasted fiom lialf an lour to one hour. Shic had recently been treated at an eye infirmary by liypodermic injections of strychnia without beneficial effect. The vision of ler $\mathbf{R}$. $\mathbf{E}=$ tingcrs ten feet, and read $\mathrm{Sn}$. $\mathrm{X}-4^{\prime \prime}$ to $6^{\prime \prime}, \mathrm{L}$. E. V. $=\frac{20}{6}$, and rcad Sn. No. III. Oplithalmoscopic 
examination manifested floating opacities in the vitreous humour of both eyes, which was much worse in the $\mathbf{R}$. E., rendcring its fundus somewhat indistinct, although its optic nerve looked very white. The L. E. manifesterl incipient disease of optic nerve and cloroid. Leeches werc ordered to be applied to her right temple. Two weeks later R. E. V. $=\frac{20}{T^{0}}$, and L. E. V. $=\frac{20}{30}$. Leeches applied to both temples, and tonic of syl: phosplate of iron, quinia, and strychnia ordered. Three weeks thereafter R. E. V. $==\frac{20}{5}$, and its fundus much more distinct, the floating opacities of vitreous smaller and less numerous. L. E. V. $=\frac{20}{90}$ minus, and its fundus clear. Lecches were again ordered to right tomple, and to continue the tonic.

February 12,1875, R. E. V. $=\frac{20}{30} ;$ I. E. V. $=\frac{20}{2}$, with fields of vision of both eyes limited above and internally. She reported that she had lier menses last week, with severe headache for scveral hours daily for three days, and after it had great dimness of vision of $I$. E. for half an hour. July 21, 1876, she reported she had married and has a healthy baby. Vitreous of both eyes were clear, and R. E. V. $=\frac{20}{3} ;$ L. E. V. $=2 \frac{0}{0}$ ininus.

CAsE IV.-Miss B., aged 18 , born in United States, was brought to my office by her family physician December 23, 1878 . About seven months previously she began to have suppression of menses, which continued three months, when her eyes commenced to pain and manifest intolerance of light. Blistering her temples had been of temporary benefit, but relapses occurred at inenstrual epochs. She has had double sight. Has now photophobia. Her pupils react fairly under light, R. E. Y. $=$ fingers five feet; L. E. V. = fingers six feet. Fields of rision of both cyes contracted, the L. F. more so than R. E. Oplithalmoscopic examination showed well-marked neuro-retinitis of both eyes, the fundus of L. E. being the one most inflamed. Advised leeches to temples, continuance of tonic, and an endeavour to secure a more free menstrual flow. She improved very little, and subsequently went to Philadelphia for treatment, where she unfortunately received no greatcr benefit, and her vision continues to be very greatly damaged.

CASE V.-Miss H., compositor, aged 18, born in United Strtes, was brought by her fatler to ine April 19, 1879, for painful and blurring vision, with freqiient disturbances from double vision, which lad prevented her using her eyes with comfort for months past. She had had a great deal of headache of late. Ascertained her menses were scanty and irregular, and she was subject to liysterical attacks. She had double sight (diplopia) to the right and left, and with R. E. alone. Her accommodative muscles were strained, as well as her internal and external recti. Ophthalmuscopic examination revealed congestion of her optic disks, also farsightedness witl astigmatism. Glasses conld not be sclected without suspending accommodation with a solution of atropia, which was done after five days' 11se of it. 'They relieved her of all double sight, and greatly improved her vision for all distances, but her cyes would not permit her to resume her work (type-setting) for fifteen months or longer, not until her menses were established regularly.

Casv VI.—Miss W., aged 20, born in United States, domestic, came to me January 5,1881 , for dimness of vision and pain in her L. E., which . began two wceks previously. A week later it pained all day, and three days later its sight becamc decidedly dimmed.

Her menses were irregular and scanty. They came on the day before 
the sight was affected. When first examined the vision of her R. E. $=\frac{1}{2} \frac{2}{0}$ in the poor light of a dark rainy day, and the L. E. could only see tire hand indistinctly one foot distant. Ophthalmoscopic examination showed inflammatory deposits upon the posterior layer of cornea and opacities of the vitreous humour. Dilated the pupil at once with a solution of atropia, which promptly relieved her pain somewhat, and continued its use. Ordered smoked glasses, bathing the eye with hot water, and leeches applied to her temple on several different occasions, and internally bichloride of mercury, as well as directions to promote free menstrual flow, which was continued for several months. Her menses became free and regular, and she fully recovered her eyesight.

CASE VII._Miss M., aged 26, school-teacher, presented herself in June, 1881, with asthenopia (weak and painful eyesight), and blephrospasm (frequent and spasmodic closure of her eyelids), due to straining of her accommodation. She lad congestion of optic disks and refiactive eye trouble, profuse leucorrhœa, and scanty menses. Suspended her accommodation and selected glasses for her, which promptly and greatly relieved lier eye troubles, and advised her to have her uterine troubles attended to, which was done with benefit. In the fall she resumed her school dities. Six or seven months later, after mental worly and return of womb troublcs, she reported, by letter; that her eyes again annoyed her, but she has not been able to visit me again.

CASE VIII._Miss P., aged 23, born in Canada, was brought by her father to me July 25,1881 , to liave her eyes examined, because she could not use them beyoun a few moments without experiencing mich pain and discomfort, although her vision was good for those few moments for all distances. She had considerable intolerance of light. When ten to twelve years of age she had nervous attacks of a choreic nature, and was kept from sehool for a ycar and a half, nor has she been permitted to go much since. She reported she had for several years past a gleat deal of headache, and her eyes had been very weak, without any external inflummatory symptoms. She has irregular menstruation with partial suppression. Ophthalmoscopic examination slowed marked congestion of both optic disks, the right one the most affected. Between three and four months treatment for suppression re-established menses, and greatly improved her general health. The congestion of optic disks was relieved, and glasses were selected to relieve her compound far-sightedness whilst the eyes were under the influence of a solntion of dnboisia, and they gave her much comfort for some months thereufter. I hear she continues to do well, and has experienced much improvement not only from lier eye discomforts but in her general health.

CASE IX.-Miss W., aged 24, a school-teacher, on December 24, 1881, called to have me examine her L. E., which nianifested a sub-conjunctival liemorrhage, that had occurred eight days previously, during the time of her menstrual flow, which was scanty. She stated she had had partial suppression of menses for many months past. Lately, at those periods sle had experienced great and unusual fulness about head and eyes. Her vision was good for all distances. No intraocular hemorrhage was found by ophthalmoscopic examination, but a slight haziness of both retina and congestion of optic nerves. Advised rest of eyes, and bathing with hot water, and to consult lier family physician about re-establishing normal menstruation.

No. CLXVIII._Oct. 1882. 
CASE X.-Miss P., aged 17, a school-girl, was brought to me January 27, 1882, by her mother for weak and painful eyes when used. Externally they looked well and healthy, and she was plump, rosy, and quite strong-looking. Two years previously she began to lave great annoyance fiom headache and pain in her eyes, and she lias had to stop going to school twice within that time on account of those sufferings. She had doublc-sight at times. Has suppression of menses. Vision was good, but she could not continuc the use of her eyes more than a few monents with comfort. She was far-sighted, and trial of weak glasses improved her vision promptly, and gave comfort to her eyes; they were ordered for her, and it was advised to have the family physician correct her suppression. Not having heard further from her, I presume she progressed fivourably.

CASE XI.-Mrs. B., aged 20, married fifteen months, called to see me March 28, 1882, about "a mistiness of sight" and intolerance of light, of two weeks' duration. She had slight conjunctivitis, and so much hyperasthesia of retina that her pupils contracted to such a small size, that oplithalmoscopic examination was impossible until they were dilated with a solution of atropial, when a haziness of the retina and congestion of optic disls were manifested, with far-sightedness. She had had suppression of menses for seven weeks. Local treatment of conjunctivitis gave her only partial and temporn'y relief. April 28th began an alterative course of internal treatment, which afforded her marked relief until the time her menses should lave occurred on May 8th, but they did not, and she relapserl. She then had had suppression three months, but no other symptoms indicating pregnancy. Leeches werc ordered to her temples, and a continuance of the medicine internally. May 30 th she reported the leeching relicved her eyes and heal considerably, and on the $22 \mathrm{~d}$, her menses came oll, and she las felt still more improvement. Examination shows less retinal haziness, and less congestion of optic disks.

CAsE XII.-MIiss N., aged 15 years, came to see me April 29, 1882, with double-sight of five months' duration, and inability to use her eyes longel than a few moments on account of spasm of accommodative nuscles She had not been able to go to school for past five or six years because of hendaclie. Two yenrs ago she had suppression of menses for three months, and then a severe spell of sick headache, since which time hel eyes have troubled her. She had congestion of optic disks. Suspension of accommotation, with a solution of duboisia for selection of glasses to correct her near-sightedness, promptly relieved her of double sight, spasm of accommodation, and headache, and seemed to afford her much comfort.

It will be observed that all the succssive foregoing cases werc unmarried persons, cxcept No. XI., and she was never pregnant. That the majority of them experienced their troubles near the beginning of their menstrual functions, or shortly afterwards. That all but one of them, No. IX., which had the subconjunctival hemorrhage, manifested disenses of the interior of the eye, and generally of the fundus, the optic nerves or retina or both of both eyes, the most sensitive and important parts of the eye. It is recorded that five of them manifested double sight, and it is remembered that several others did also. Relapses occurred so oftell at the time of menstrual disturbance that the connection between them seems most conclusive. Also, when normal menstruation was reestablished and maintained, their eyes gave them no further trouble. 
They were all relieved except Cases No. II. and No. IV. The former soon passed from observation with grave symptoms of a cerebro-spinal character. The latter, when first examined, manifested the greatest loss of vision of any of them; fingers could be counted from five to six fcet only, and internal examination revcaled considerable inflammatory exudation into papille and retine, which threatened their atroply with loss of function beyond recovery. Cases of this kind demand prompt recognition as to their etiology (betore vision is too mucl impaired by the internal eyc disease) in order that they may be successfully treated and relieved. Partial loss of vision, and inability to nse the eyes in young liealthy-looking females, without external eye disease, always suggest to my mind the probabilitics of menstrual disturbances, and it is inquired about. As many more cascs could be presented as the foregoing; but it is decided not to do so because they werc not fully recorded, and could only numerically enlarge the observations I wish to present. Young school-girls often manifest asthenopia (wcak and painful siglit) about the time their menses are being established, and especially if their menses become irregular fiom any cause, whicl may producc partial or complete suppression for an indefinite time. I will not further pursue this subject to present illustrative cases, but state that sometimes they manifest decided congestion of optic papille and retine, and others no interual eye lesion, with the exception of strain of their accommodation which is common to all of these cases, for they have some refractive deformity of their eyes, which, sooner or later, causes their muscles of accommodation to rebcl from their over-taxing and too continuous work.

The irregularities of the monopause period is often complicated with asthenopia and pathological lesions of the fundns of the eye. Severul cases of this nature, with disease of the optic ncrve and retina fiom their incipiency to their complete atroply, have been under observation recently.

Only uncomplicated cases as to their ctiology lave been selected for this paper, and all others excluded for various reasons, but especially for brevity, and to definitely establisl the intimate and practical relations existing between eye diseascs and menstrual disorders.

Article V.

On the Mild Forms of Continued Fevels which Purvail in Washington, with suggestions as to thelr Nature. By W. W. Johnston, M.D., Prof. of the Theory and Practice of Medicine, Medical Department of the Columbian University; one of the Plysicians to the Children's Hospital.

The forms of continued fever which prevail in Washington may be classed as follows :-

I. Cases of typloid fever with well-defineil pathognomonic symptoms, 